\title{
Acute hypothyroidism in a severely ill surgical patient
}

A case of acute postoperative hyporhyroidism in a 62-year oid woman is presented. One monh before emergency admission because of a perforated gastric wlcer the patient had normal thyroid function, despite removal of a shyroid adenoma 20 years earlier. Following surgery the patient developed circulatosy instabilin, renal insufficiency, hypothermia and immeasurable concentrations of thyroxine $\left(T_{4}\right)$ and triodothyronine $\left(T_{3}\right)$. Treatment with triiodothyronine was commenced but the patient died following an episode of severe hypotension.

During acute illness in euthyroid patients, peripheral thyroid hormone metabolism is altered, resulting in the "sick euthyroid syndrome", 1 in which the laboratory findings characteristically are low 3,5,3' triiodothyronine $\left(T_{3}\right)$ and thyroxine $\left(T_{4}\right)$, normal free $T_{4}$ and $T S H$, and an elevated 3,3',5' triiodothyronine (reversc $T_{3}, \mathrm{rT}_{3}$ ). ${ }^{1}$ The role the "sick euthyroid syndrome" may play in increasing operative risk has not been determined.

This case report describes a patient with clinical symptoms of hypothyroidism and very low $T_{3}$ and $T_{4}$ after a severe surgical illness, despite evidence of normal thyroid function one month before the acute illness.

\section{Case report}

A 62-year-old woman was admitted with a three-day history of abdominal pain and vomiting. The patient gave a ten-year history of polymyalgia rheumatica treated with non-steroidal antiinflammatory dnugs and for short periods with corticosteroids. Twenty years earlier she had undergone surgical removal of a thyroid adenoma. After this operation thyroid function was normal, and no medical therapy was required. One month before the current admission the patient complained of increasing muscle pains and investigation revealed the following: haemo-

\section{Key words}

HORMONES: thyroid, hypothyroidism; COMPLICATIONS: acute myxoedema.

From the Department of Anaesthesiology, University of Copenhagen, Hvidovre Hospital, Kettegards Alle, DK 2650 Hvidovre, Denmark.

Address correspondence to: Dr. Mogensen. globin $6.6 \mathrm{mmol} \cdot \mathrm{L}^{-1}$, leucocyte count $9.65 \times 10^{9} \cdot \mathrm{L}^{-1}$, serum TSH $1.1 \mathrm{mU} \cdot \mathrm{L}^{-1}$, serum $\mathrm{T}_{4} 107 \mathrm{nmol} \cdot \mathrm{L}^{-1}$ (65-155). Treatment for polymyalgia theumatica with prednisone $15 \mathrm{mg} /$ day $\mathrm{PO}$ was started.

On the day of admission the patient was palc, with clinical signs of ileus, but her level of consciousness was normal. The thyroid gland was not enlarged. Blood pressure was $110 / 80$, heart rate $150 \cdot \mathrm{min}^{-1}$. Laboratory investigation showed: haemoglobin $7.8 \mathrm{mmol} \cdot \mathrm{L}^{-1}$, leucocyte count $9.7 \times 10^{9} \cdot \mathrm{L}^{-1}$, platelets $239 \times 10^{9} \cdot \mathrm{L}^{-1}$, serum potassium $5.9 \mathrm{mmol} \cdot \mathrm{L}^{-1}$, sodium $130 \mathrm{mmol} \cdot \mathrm{L}^{-1}$, creatinine $249 \mu \mathrm{mol} \cdot \mathrm{L}^{-1}$.

The patient was transfented to the operating theatre where a perforated gastric ulcer with severe peritonitis was found, during 90 minutes of uncomplicated diazepam/fentany? anaesthesia. There were no signs of hypoxaemia and the lowest recorded blood pressure was 100/60.

After the operation (oversewing of the ulcer) the patient was admitted to the Intensive Care Unit, because of respiratory insufficiency. Postoperatively she was unconscious, with a weak reaction to painful stimuli. Her temperature was low $\left(36.6^{\circ} \mathrm{C}\right)$ immediately postoperatively and fell further to $35.5^{\circ} \mathrm{C}$ during the next ten days. Culture of the abdominal wound showed E. Coli and treatment with netilmicin and ampicillin was begun. The serum concentration of metilmicin never reached toxic levels.

One week later, the leucocyte count had fallen from $11.4 \times 10^{9} \cdot \mathrm{L}^{-1}$ to $5.4 \times 10^{9} \cdot \mathrm{L}^{-1}$. Steroid treatment was continued throughout the admission with cortisone 100 $\mathrm{mg} /$ day IV.

The cardiovascular status was initially good but one week later treatment with dopamine $7.0 \mu \mathrm{g} \cdot \mathrm{kg}^{-1} \cdot \mathrm{min}^{-1}$ was necessary to maintain circulatory stability. All efforts to wean the patient from the ventilator were unsuccessful. Haemodialysis was started because of increasing renal insufficiency. Twelve days postoperatively the serum $T_{4}$ concentration was $<20 \mathrm{nmol} \cdot \mathrm{L}^{-1}$ and the $\mathrm{T}_{3}$ was $<0.5$ $\mathrm{nmol} \cdot \mathrm{L}^{-1}(1.6-2.9)$. Treatment with triiodothyronine 10 $\mu g$ IV three times daily was initiated, but the patient dicd two days later following cardiovascular collapse, with severe hypotension and bradycardia $<50$ beats $\min ^{-1}$, despite dopamine $15 \mu \mathrm{g} \cdot \mathrm{kg}^{-1} \cdot \mathrm{min}^{-1}$. Body temperature remained below $36^{\circ}$ throughout the course of treatment. 
An EEG performed the day before death showed severe diffuse changes consistent with hypoxaemia.

Postmortem examination revealed an enlarged thyroid gland with small nodular cystic areas. A severe generalized peritonitis was also found and the kidneys showed signs of acute diffuse interstitial nephritis. All other organs appeared normal.

\section{Discussion}

Alteration in thyroid function during non-thyroid illness has been long appreciated. ${ }^{2}$ Kaptein et . $^{3}$ found that in critically ill patients there was a correlation between decreases in free $T_{4}$ and increased mortality. The serum $\mathrm{T}_{4}$ may be a marker of severity of illness. Low serum $\mathrm{T}_{4}$ concentration is associated with poor prognosis. However, it remains to be established whether this is in fact a causal relationship. It is not clear whether changes in thyroid function contribute to morbidity or are merely a normal response to injury.

The absence of a serum TSH elevation despite low circulating levels of $T_{3}$ and $T_{4}$ has been taken as evidence of euthyroidism in non-thyroid illness. ${ }^{2}$ Another explanation could be that the action of thyroid hormones on the pituitary gland is distinet from their action on peripheral tissue, suggesting that TSH may not be the best indicator of euthyroidism. ${ }^{4}$ Becker et al. ${ }^{5}$ found a very high metabolic rute in patients with burn injuries, despite a low free fraction of thyroid hormone and suggested that the increase in metabolic rate was due to an increase in catecholamines. Furthermore, treatment of a group of patients with triiadothyronine did not influence survival rate.

The decrease in serum $\mathrm{T}_{3}$ and increase in $\mathrm{rT}_{3}$ levels in nonthyroidal illness result from decreased 5 -monodeiodinase activity. About $80-100 \mu \mathrm{g}$ of $\mathrm{T}_{4}$ and $30 \mu \mathrm{g} \mathrm{T}$ are produced daily. The half-life of $T_{4}$ is approximately one week, that of $T_{3}$ approximately 24 hours. Thyroid hormone production is regulated through a "feedback loop" by TSH. TSH production increases when serum $T_{4}$ falls. The relative metabolic activity of $T_{4}, T_{3}$ and $r T_{3}$ are 1:3:0.75.

Zaloga et al. ${ }^{6}$ in a longitudinal study found a decrease in thyroid function one day after cardiac surgery, with normal function four weeks later.

Hypothyroidism produces major derangements of nomal physiology, including depression of myocardial function and decreased hypoxic and ventilatory responses. Thyroid supplements should be given preoperatively to hypothyroid patients before emergency surgery. ${ }^{7}$ Our patient had a history of thyroid discase many years before the current admission. Thyroid function was normal one month before admission but, as shown during subsequent pathologic examination, there was multinodular enlarge- ment of the gland. Postmortem examination, however, did not explain the cause of the hypothyroidism after the surgical stress. Our patient had many clinical signs of impaired thyroid function: low temperature, decreased cardiovascular function and mental disturbance.

Dopamine infusion lowers both basal TSH and blunts the TSH response to $\mathrm{TRH}$,' suggesting a physiological role for endogenous dopamine in the control of TSH secretion. The clinical implication of this is small and should not lead to diagnostic confusion. ${ }^{1}$ However, these symptoms are nonspecific in intensive care patients and at present there are no data to support routine thyroid hormone treatment of patients with the "sick euthyroid syndrome."

Post-injury changes in thyroid function and their possible role in increasing morbidity in severely ill patients deserve further study.

\section{References}

1 Wartofsky $L$, Burman $K D$. Alterations in thyroid function in patients with systemic illness: the "Euthyroid Sick Syndrome." Endocr Rev 1982; 3: 164-217.

2 Burger A, Nicod P. Suter $P$, Valioton $M B$. Reduced active thyroid hormone levels in acute illness. Lancet 1976; 1: $653-5$.

3 Kaptein EM, Weiner JM, Robinson WJ, Wheller WS, Nicoloff JT. Relationship of altered thyroid hormone indices to survival in nonthyroidal illness. Clinical Endocrinology 1982; 16: 565-74.

4 Bacci V. Schussler GC, Kaplan $T$, The relationship between serum triiodothyronine and thyrotropin during systcemic illness. J Clin Endocr Met 1982; 54: 1229-35.

5 Becker RA, Vaughan GM, Zeigler $M G$ et al. Hypermetabolic low triiudothyronine syndrome of bum injury. Crit Care Med 1982; 10: 870-5.

6 Zaloga GP, Chenow B, Smallbridge $R C$ et al. A longitudinal cvaluation of thyroid function in critically ill surgical patients. Ann Surg 1985; 456-64.

7 Murkin $J M$. Anesthesia and hypothyroidism: A revjew of thyroxine physiology, pharmacology, and anesthetic implications. Anesth Analg 1982; 61: 371-83.

\section{Résumé}

Un cas d' hypothyroüdisme aigu postopératoire chez une patiente àgée de 62 ans est présenté. Un mois avant son admission a l'urgence da cause d'un ulcère gastrique perforé la pariente a présenté une fonction thyroïdienne normale malgré l'exérèse d' un adénome thorö̈lien 20 ans auparawant. Après la chirurgie la patiente a développé une instabilité circulatoire, une insuffisance rénale, une hypothermie et une baisse prononcée des concentrations de thyroxine $\left(T_{4}\right)$ et de triiadothyronine $\left(T_{3}\right)$. Le traitement avec de ia triiadothyronine fut établi et la patiente développa une épisade d' hypotension sévère. 